\title{
Slovenský literárny kánon v uhorskom \\ a česko-slovenskom kontexte (Náčrt problematiky)
}

Peter Káša (Prešov)

\begin{abstract}
Abstrakt
Slovenská literatúra sa celé stáročia formovala $v$ tesných kontaktoch a v symbióze so susednými literatúrami. Slovenský etnický priestor bol prirodzenou súčastou Uhorska a širšej strednej Európy. Kánon slovenskej literatúry vytvárali autori vo viacerých jazykoch (latinský, český, nemecký, slovenský, mad’arský). Slovenskú literatúru dnes reflektujeme ako texty autorov so slovenským pôvodom alebo texty autorov, ktorí žili a tvorili na území Slovenska. Charakter literatúry však v rôznych obdobiach podmieňovali aj aktívne slovanské väzby a skrytá spoločná kultúrna pamät'. Od začiatku 19. storočia možno hovorit' o programovej profilácii slovenského národného kánonu ako novej a dynamickej autonómnej štruktúre v rámci slovanského, česko-slovenského a uhorského kontextu.
\end{abstract}

\section{Klúčové slová}

kánon; literatúra; kontext; Uhorsko; slovenský; český; mad’arský

\begin{abstract}
The Slovak Literary Canon in the Hungarian and Czecho-Slovak Context

Slovak literature have been developing in close contact with literatures of the neighbouring regions. Slovak ethnics pace has been a natural part of both former Austro-Hungarian Empire (and Hungary as well) and a broader Central Europe. The Slovak literary canon has been formed by the authors using different languages (Latin, Czech, German, Slovak and Hungarian). At present, Slovak literature can be understood as literature by the authors with the Slovak background or written by the authors who have been living and working on the territory of current Slovakia. The nature of Slovak literature, however, was considerably influenced by other Slavic literatures and a hidden common culture consciousness. It can be argued that since the beginning of the 19th century the Slovak literary canon started to develop as a new, dynamic and autonomous structure within Slavic, Czechoslovak and Hungarian contexts.
\end{abstract}

\section{Keywords}

canon; literature; context; Hungary; Slovak; Czech; Hungarian 
V súčasnej európskej humanistike, napriek výraznej dynamizácii interkultúrnej komunikácie, sa vo vzdelávacom systéme v minimálnej miere mení podstata a charakter literárneho kánonu. Výnimkou nie je ani slovenský literárny kánon, ktorý sa len výnimočne prezentuje v otvorených dialógoch a interkultúrnych súvislostiach minimálne v stredoeurópskom kontexte a vo vztahoch $\mathrm{k}$ najbližším susedom - Čechom a Mad’arom, s ktorými Slováci zdielajú spoločnú historickú a kultúrnu pamät. Ambivalencia medzi slovne deklarovanou „európskou“ otvorenostou (dialogickostou) a reálnou „národnou“ uzavretostou (monologickostou) je markantná. Deficit sa prejavuje najmä na všetkých stupňoch vzdelávacieho systému, vrátane vysokoškolského. Je to paradox, lebo otázka prezentovania národných kánonov ako foriem kultúrnej pamäti sa môže stat jedným z aktuálnych a klúčových problémov pri hladaní optimálneho „európskeho“ modelu humanitného vzdelávania a kultúrnej politiky v časoch stupňujúceho sa nacionalizmu a pretrvávajúcej relativizácie hodnôt. „V súčasnej literárnej vede sú zaužívané minimálne dve, viac-menej jasne diferencované ponímania kánonu. Prvé predstavuje širšie, stabilnejšie a časovo rozsiahlejšie chápanie pojmu, ktoré sa vzṫahuje na kultúru a kultúrnu pamät', druhé tvori užšia a teoreticky mierne modifikovaná koncepcia kánonu v rámci konkrétnych interpretačných spoločenstiev. " Pojem kánon, ktorý sa v súvislosti s literatúrou používa od 18. storočia obyčajne označuje súbor/korpus textov, ktoré profilujú a kodifikujú hodnotový systém istej sociálnej skupiny na báze regionálnej, etnickej, politickej či konfesionálnej súdržnosti. Literárny kánon tak vytvára a kóduje rozličné podoby estetických, ale aj etických a ideových noriem, ktoré spoločenstvo nielen reprezentujú, ale aj vymedzujú voči iným spoločenstvám. Č́m je spoločnost homogénnejšia, tým je pravdepodobnejšie, že sa v ňom kreuje jeden alebo minimum kánonov. Naopak, vnútorne diferencovanú spoločnosṫ charakterizuje pluralita kánonov, ktoré neexistujú výlučne len vedla seba alebo proti sebe, ale sa transformujú, prelínajú a presiełujú. „Kánon ako organizačný princíp kultúrnej pamäti má dosah na spoločnú pamät' zakladajúcu sa na textovej koherencii - a síce cez rôzne kanály spoločenskej verejnosti (učebnice, inštitucionálne vzdelávanie, štátna kultúrna politika, kritika, veda o umeniach)."

Permanentnou rekonfiguráciou „textov a interpretácii“" vznikajú heterogénne pestré formy kultúrnej pamäti. Takmer v absolútnej podobe to platí pre strednú Európu, ktorú charakterizuje etnická, kultúrna i konfesionálna pluralita. „Středoeuropský komplex se svou promènlivou pozici nestabilných center a periferii a se specifickým prolnutím národností, kultur a náboženstvi je paradoxně ,odsouszen " $k$ respektováni kulturni různorodosti a odlišnosti, $k$ trualé kritice úzce etnocentrického principu. “3 Podobne ako český literárny komparatista Miloš Zelenka uvažuje o týchto otázkach aj rakúsky kulturológ so spišsko-uhorskými koreňmi Moritz Csáky, ktorý pripomína, že „jednota stredoeurópskeho regiónu existovala iba vd’aka endogénnej a exogénnej pluralite a heterogenite “. ${ }^{4}$ Premenlivost' a dynamickost' považuje za podstatu a paradoxne stabilizujúci faktor stredoeurópanstva aj Ivo Pospísil:

1 BOKA, László: Paralelnosti teorie kánonu: literárněhistorické aspekty. World Litarature Studies 7, 2015, č. 3, s. 4.

2 Tamtiež, s. 8.

3 ZELENKA, Miloš: Literární věda a slavistika. Praha: Academia, 2002, s. 65.

4 CSÁKY, Moritz: A kommunikációs térként értett kultúra. Közép Európa példája. Irodalomtörténet XLI, 2010 , č. 1, s. $5-6$. 
„Toto přesouváni, neustále vnitřni přestavováni fenoménu středoevropanstvi je jeho dezintegrujicim, slabým mistem. Tato labilita, která pưsobi rozkladně, je však současně jeho stabilitou. " ${ }^{5}$ Som presvedčený, že práve v týchto dynamických a premenlivých „vztahoch a kontaktoch“ je potrebné neredukovane a zmysluplne prezentovat aj slovenský literárny kánon. V príspevku sa síce zameriavam iba na uhorský (slovensko-mad’arský) a česko-slovenský kontext, ale v perspektívnom výskume nechcem vynechat ani širšie stredoeurópske súvislosti. Konkrétne ide o komparatívnu reflexiu málo známych a takmer zabudnutých diel nemeckých, rusínskych a židovských autorov. ${ }^{6}$

Prirodzene, že túto tézu „otvorenosti a heterogénnosti“ slovenskej literatúry sformulovali už viacerí literárni vedci, ale napriek tomu tento viac problémový a problematizujúci variant sa do dnešných dní nestal prirodzenou súčastou akademickej ani školskej prezentácie. Jeden z najvýznamnejších slovenských literárnych historikov minulého storočia Stanislav Šmatlák ešte v roku 2002 napísal: „Slovenská literárna tvorba sa za velmi dlhý čas realizovala vo viacerých etnicky nevlastných jazykových formách (latinčina, čeština, nemčina, sčasti mad’arčina). "7 Prirodzene, že tieto „nevlastné formy“ v národných literatúrach, ktoré dnes vnímame ako kanonické diela, reprezentovali typický heterogénny a variabilný celoeurópsky model a slovenský literárny život vo svojich kontextoch nebol v ničom špecifický a výnimočný. Nie je to však jediný spôsob prezentácie, lebo v tom istom čase v úvodnom slove Slovnika slovenských spisovatelov Valér Mikula poznamenáva: „Aj slovenská literatúra sa vo významne prevažujúcej časti svojej doterajšej existencie vyvijala v rámci multietnických či viacnárodných štátov (uhorského, rakúskeho či rakúsko-uhorského) a texty, ktoré do nej zarad'ujeme, tvorili (s výnimkou folklóru) súčast’ väčšch kultúrnych celkov a podiel'ali sa na ich budovaní." ${ }^{8}$ Rovnako aj Eva Tkáčiková zdôrazňuje, že: „Rešpektujúc viackontextovost' a viacjazyčnost’ našej literatúry zahŕñame do pojmu národná literatúra všetky diela, viažuce sa k teritóriu obývanému Slovákmi, $t$. j. diela, ktoré boli rozširované, recipované a pôsobili v kontexte nášho kultúrneho vývinu. Súčastou vývinu národnej literatúry sú tak diela písané v rozličných jazykoch a jazykových variantoch."9

Korpus slovenského literárneho kánonu v diachrónnej rovine otvára všeobecne prijatá a zaužívaná téza, že počiatky slovenskej literárnej vzdelanosti sú späté s vel'komoravskou štátnostou a duchovnou kultúrou a tzv. staroslovienskym literárnym jazykom. V tomto období sa vytvárajú prvé „vztahy a kontakty“ slovenského kultúrneho priestoru medzi

5 POSPÍŠIL, Ivo: Areál a filologická studia. Brno: MU, 2013, s. 20.

6 Podrobnejšie k týmto otázkam pozri: MIKULÁŠEK, Alexej a kol.: Literatura s hvězdou Davidovou. Olomouc: Votobia, 1998; PETRAŠKO, Ludovít: Blizki vzdáleni. Slovensko-nemecké (nielen) literárne vztahy. Prešov: Vydavatel'stvo Prešovskej univerzity, 2013; TERRAY, Elemír - BOK, Václav: Deutschsprachige Literatur. Diel 1. Bratislava: SPN, 1991; MAGOCSI, Paul Robert: Chrbtom k horám. Dejiny Karpatskej Rusi a Karpatských Rusínov. Prešov: UNIVRSUM, 2016.

7 ŠMATLÁK, Stanislav: Dejiny slovenskej literatúry I. Bratislava: LIC, 2002, s. 21.

8 MIKULA, Valér: Úvodná štúdia. Slovenská literatúra. In: Slovník slovenských spisovatelov. Praha: Libri, 2000, s. 13 .

9 TKÁČIKOVÁ, Eva: Literárna kultúra na stredovekom Slovensku. In: SEDLÁK, Imrich a kol.: Dejiny slovenskej literatúry I. Bratislava: LIC, 2009, s. 11. 
Byzanciou a Rímom. Staroslovienčina vytvára najstaršiu a prvotnú celoslovanskú cirkevnú a kultúrnu bázu. V kontakte so silnejšou a razantnejšou latinčinou sa staroslovienčina v slovenskom prostredí dlho neudržala. Dlhodobo prežíva v subštandardných podobách ako skrytá či latentná forma kultúrnej pamäti. Slovanské (slovienske) vedomie slovenskej kultúrnej identity však od 11. storočia úplne nezaniká, ale adaptuje sa v nových a zložitejších politických a sociálnych pomeroch uhorského královstva a politického stavovského národa „Natio Hungarica“. Slovenská kultúrna identita sa tak niekol'ko storočí uchováva v nových štruktúrach širšej a univerzálnejšej uhorsko-latinskej stredovekej vzdelanosti. Prvým významnejším dielom dokázatel'ne slovenskej proveniencie bola Maurova legenda o sv. Svoradovi a sv. Benediktovi (1037). Je to však aj prvá latinská uhorská legenda, obsahujúca elementy slovenské i mad’arské. Teda nie je ani čisto slovenská, ani čisto mad'arská z pohladu súčasných parametrov „národnosti“.

Kontexty a kontúry slovenského literárneho kánonu sa opät výraznejšie transformujú s nástupom reformácie od polovice 16. storočia. Postupne sa diverzifikujú v dvoch konfesionálnych ideových štruktúrach: slovensko-uhorskom a svätoštefánsko-mariánskom katolicizme („Regnum Marianum“) a v slovensko-českom, neskôr československom protestantizme. Táto dvojpólovost̉ bola principiálna a dôsledná nielen v rovine cirkevnej ideológie a náboženského života, ale aj praktickej literárnej produkcie a jej recepcie. Podoba a charakter literárneho života v slovenskom prostredí postupne menila aj čeština ako nový „literárny jazyk“ slovenských vzdelancov. Nielen evanjelici, ale aj katolíci píšu od začiatkov reformácie až do konca 18. storočia slovakizovanými variantmi češtiny a používajú českú náboženskú literatúru. Treba však poznamenat', že rekatolizácia sa v slovenskom ludovom prostredí najefektívnejšie rozširovala nie prostredníctvom vysokej „biblickej češtiny“, ale cez živý „domáci jazyk“ v rozličných regionálnych variantoch, nazývaný aj jezuitskou slovenčinou (Ostrihomský rituál, Canthus Catholici a pod.). ${ }^{10}$ Tento systém profilovania kultúrnej identity cez paralelné jazyky a literárne kánony výraznejšie narušili až prvé prejavy slovenského národného hnutia v čase romantizmu. Symbolickým začiatkom nadkonfesionálneho národného zjednocovania a profilovania jedného literárneho spoločenstva bolo vydanie literárneho almanachu Zora (1835). Od tohto momentu sa aj slovenský literárny kánon profiluje štandardne a modelovo v reláciách európskeho jazykového či kultúrneho nacionalizmu: jeden jazyk - jedna historická tradícia - jedna literatúra - jeden národ.

Zárodky „užšieho“ slovenského, ale aj mad’arského národného literárneho kánonu možno skonštruovat len na báze „širšieho“ uhorského kultúrneho kontextu (Hungarus) a v intenciách feudálnej a osvietenskej koncepcie národa („Natio Hungarica“) na základe latinských literárnohistorických prác z obdobia osvietenstva. V týchto súvislostiach slovenská i mad’arská literárna veda jednotne uvádza dielo Pavla Valaského/Pavllo Wallasz-

10 Podrobnejšie k tomu pozri BANÍK, Anton A.: O dialektickej podstate slovenského konfesionalizmu. Martin: Matica slovenská, 2000, s. 39 - 58. 
ky (1742 - 1824) Conspectus reipublicae Litterariae in Hungaria (1785). ${ }^{11}$ Ide o prehladné dejiny literatúry, kde autor spracoval uhorskú literárnu minulost', teda zoznam „uhorských“ spisovatel'ov od najstarších čias bez rozdielu národnosti. V súvislosti s kánonom je zaujímavé a dôležité to, že v úvode sa poznamenáva, že z literárnych dejín sa dozvedáme „o dobrých a zlých knihách“, a že mnohé diela „vel'kých mužov literatúry treba nasledovat". Tieto diela mali „bránit"“ uhorskú literárnu vzdelanost̉ a vlastný domáci literárny kánon, teda národnú dôstojnost̉ pred nemeckou kultúrnou nadradenostou. Autor prezentuje starobylost’ a kultúrnu tradíciu univerzálnej a etnicky indiferentnej uhorskej kultúry. O dvadsat rokov neskôr, ked' vychádza druhé vydanie, sa už výraznejšie mení aj spôsob prezentácie spoločnej uhorskej literárnej histórie. Postupná jazykovo-etnická diverzifikácia znamená proces profilovania a emancipácie nových národných literárnych komunít. Začína sa tak obdobie narúšania mnohých spoločenských noriem a konvencií, a teda aj literárnych kánonov. V roku 1808, ked’ vychádza už po mad’arsky písané dielo Samuela Pápayho A magyar irodalom esmerete, vydáva aj slovenský básnik Bohuslav Tablic Paměti česko-slovenských básnírưv (1806 - 1812). Obaja autori už jasne deklarujú, že moderná postbaroková literárnost’ sa už nespája len s univerzálnou latinčinou, ale aj (najmä) s národnými jazykmi (mad’arčina a čeština). Touto metódou rekonštrukcie literárnych dejín sa však postupne redukuje a transformuje slovenský i mad’arský literárny kánon. Latinské, nemecké a mad’arské texty sa v tvoriacom sa slovenskom (česko-slovenskom či česko-slovanskom) národnom kánone postupne dostávajú „z centra na periférium“ ako texty „nepravé a nepodstatné“, teda nekanonické. Slovenská literárna história to interpretovala tak, že „Valaský so svojou uhorskou orientáciou nezapadol do koncepcie slovenského národného obrodenia“. Naopak, „Tablic poukázal na osobitost' a národný svojráz slovenskej literatúry, čím vymedzil kontúry jazykovo-etnickej normy čítania a interpretovania literárnych textov". ${ }^{2}$ Výklad multietnického a heterogénneho uhorského literárneho kánonu sa od začiatku 19. storočia stále intenzívnejšie prispôsobuje modernému, ale v mnohom zredukovanému národnému diskurzu. Do značnej miery ide o umelé akési „ex post“ vyčlenenie súboru písomností podla miestnej či etnickej príslušnosti autorov (domáci pôvod či pobyt na území Slovenska) alebo podla podobnej 'príslušnosti' textov (vztahovanie sa na Slovensko, tzv. slovaciká). Ako však presne poznamenáva V. Mikula: „Takýto postup je však všeobecne prijimaný a uplatňuje sa predovšetkým vo väčšine menšich literatúr, ktoré nevznikli v rámci národných štátov." ${ }^{3}$

Zo slovenského pohladu je však problematická aj „centralizujúca“ optika tzv. vel’kých či väčších literatúr. Napríklad v mad’arskej literárnej histórii sú kanonizované všetky texty z uhorského teritória (až do obdobia romantizmu) cez úzky a uzavretý jazykovo-etnický hodnotiaci prívlastok „magyar irodalom“ (mad’arská literatúra) a nie cez širší a otvorený teritoriálne-kultúrny „magyarországi alebo magyarhoni irodalom“ (uhorská literatúra). Empatický a tolerantný prístup rešpektuje a minimálne nezamlčuje prirodzenú zásadu, že takmer všetky stredoeurópske literatúry sa v novodobých dejinách generovali

11 VALASKÝ, Pavol: Conspectus reipublicae litterariae in Hungaria ab initiis regni ad nostra tempora delineatus. 1. vyd. Bratislava - Lipsko, 1785; 2. vyd. Budín, 1808.

12 KRAUS, Cyril: Začiatky slovenskej kritiky. Bratislava: Veda, 1991, s. 16 a 37.

13 MIKULA, Valér: Op. cit., s. 13. 
a prezentovali v rozličných heterogénnych a multietnických kultúrnych spoločenstvách a na báze: 1) inštitucionálne-teritoriálnej (uhorský kontext); 2) konfesionálne-jazykovej (česko-slovenský kontext); 3) kultúrno-genetickej (slovanský kontext). Kanonizované spoločenstvá národných literatúr, ktoré dnes reflektujeme v rámcoch, ako sa „vyčleňovali a vymedzovali“ voči iným (cudzím) literatúram, existovali v prirodzených multietnických heterogénnych spoločenstvách. V tejto súvislosti mad’arský literárny historik I. Käfer navrhuje, aby tento literárny a kultúrny fenomén bol predmetom špecifických/alternatívnych mad’arských i slovenských humanitných vedecko-pedagogických poddisciplín: hungaroslovakológia a slovakohungarológia. ${ }^{14}$ Tento projekt je síce vedecky korektný a empatický voči druhému, ale v mnohom aj iluzórny. Je tažko aplikovatel'ný najmä v oblasti vzdelávania, kde sa staršie literatúry (dokonca aj v akademickom prostredí) ocitli na úplnom okraji záujmu vedeckej i didaktickej reflexie. Možno, a to je asi reálnejšie, že Käferom prezentované a preferované problematické otázky kultúrnej histórie by sa mohli stat’ integrálnou súčastou spoločných slovensko-mad’arských učebníc dejepisu, ako primeranej dialogickej platformy pre literárnu históriu.

Slovenský národný literárny kánon sa tak od druhého decénia 19. storočia programovo profiluje ako nová a dynamická autonómna štruktúra v rámci slovanského, česko-slovenského a uhorského kontextu. Prelomom je dielo P. J. Šafárika, ktorého počas štúdií na lýceu v Kežmarku podporoval aj jeden z posledných „uhorských vlastencov“ a zástancov latinčiny Gregor Berzevici. Mladý Šafárik sa práve v tejto vzdelávacej inštitúcii konfrontoval so starou klasickou vzdelanostou (latinský a nemecký literárny kánon), ale aj s prvými prejavmi českého národného obrodenia (J. Jungmann). Vo svojom po nemecky napísanom diele o dejinách slovanských jazykov a literatúr bol prvý, ktorý 1) komplexne predstavil kontúry slovanskej kultúry cez vnútorne diferencovaný systém príbuzných jazykov a literatúr; 2) predstavil „jazyk a literatúru Slovákov“. Inými slovami, vytvoril prvotný kánon slovanských literatúr i kánon slovenskej národnej literatúry, ktorý je definitívne vyčlenený z tradičného uhorského a čiastočne i československého literárneho spoločenstva. Šafárikova prezentácia slovenskej literatúry kanonizovala nielen „súbor autorov a textov“, ale aj (najmä) obrat v slovenskej kultúrnej tradícii od „uhorského k česko-slovenskému a slovanskému kontextu“. Nový spôsob profilovania literárneho kánonu a generovania slovenského kultúrneho kódu sa v dejinách literatúry realizoval aj kanonizovaním „národného zmieru“, novej jednoty medzi vzdelancami a spisovatelmi katolíckeho a evanjelického vierovyznania. S dávkou zjednodušenia by sa dalo povedat, že formovanie jadra slovenského národného literárneho kánonu sa spája s kultúrnym prostredím Pešti a Budína, ktoré boli celé 19. storočie dominantnými centrami slovenského spoločenského a kultúrneho života. (Budinska univerzitná tlačiareñ, Spolok milovnikov reči a literatúry slovenskej, almanach Zora... ). Bodom obratu sú teda dvadsiate a tridsiate roky 19. storočia, ked’ vychádzajú dodnes klúčové kanonické texty slovenskej literatúry: Ján

14 Podrobnejšie k tomu KÄFER, István: Magyar szlovákságismeret. Budapest: Szent István Társulat, 2012. 
Kollár Slávy dcera (1. vyd. Budín, 1824; 2. vyd. Pešt', 1832) a trilógia národných hrdinských eposov J. Hollého (Svatopluk, Cirilometodiáda a Sláv).

Je to paradox, ale kánon, ktorý sa reálne formuje v uhorskom prostredí, svojím tematickým zameraním a hlbšou ideológiou práve z tohto sveta vystupuje. Vyššie uvedené texty v alegorickej podobe reprezentujú mnohé znaky slovansko(slovensko)-mad’arského antagonizmu v Uhorsku. Pre slovenských romantikov to boli iniciačné texty, ktoré sa postupne kanonizovali, aby sa od roku 1918 až do dnešných dní s minimálnymi korekciami inštitucionalizovali naprieč všetkými režimami i politickými systémami. V týchto textoch je totiž výrazne zakódované protimad’arské (nepriamo aj protiuhorské) politické gesto, ako reakcia na stupňujúcu sa etnickú netoleranciu mad’arskej elity a neskôr uhorskej vlády v celom 19. storočí. Aktivity slovenských študentov na evanjelických lýceách (Bratislava, Levoča, Kežmarok, Prešov...) tento obrat potvrdzujú a radikalizujú. Popri mad’arských a nemeckých vznikajú aj slovansko(slovenské) katedry a študentské spoločnosti, kde k povinnému čítaniu patrili „kanonické“ diela J. Kollára, J. Hollého a d’alších slovanských básnikov. Ako sme už naznačili, problematika reálnej identifikácie novodobého slovenského národa ako modernej entity sa takmer vždy prejavovala v dvoch základných rovinách: 1) v rovine vnútornej sebaidentifikácie (vlastný jazyk, literatúra, dejiny, folklór...); 2) v rovine definovania sa navonok (vzţah k užšiemu a širšiemu geopolitickému a geokultúrnemu priestoru).

Obidve tieto tendencie sa dopĺňali a vnútorne koexistovali. Neraz vznikala zložitá siet’ vztahov a väzieb, do ktorej sa zaplietli mnohí národovci - kriesitelia nových ideí a programov. Po J. Kollárovi a P. J. Šafárikovi nastúpila generácia mladoslovákov - štúrovcov, ktorá sa pokúšala vypracovat’ celoslovenský (nadkonfesionálny a nadregionálny) národnobuditel'ský program. Rozvíjala projekt inštitucionalizácie vznikajúceho slovenského národného života. Najmä protagonista tohto hnutia, L. Štúr, so sebavedomým gestom európsky rozhladeného národného liberála predstavil v štyridsiatych rokoch 19. storočia svetu Slovákov ako špecifické a jedinečné etnikum. Zaujímavé je to, že nový kánon slovenskej literatúry prezentoval cez prednášky o „slovanskej poézii“. Prelomom pri formovaní literárneho kánonu bola „dohoda“ o používaní nového literárneho jazyka (1843) a prvá kniha v spisovnej slovenčine almanach Nitra II (1844). Neskôr vychádza gramatika, literárne časopisy Orol Tatranský a Slovenské pohl’ady, klúčové predpoklady pre formovanie a legitimizáciu kultúrneho kánonu. Možno povedat', že tento národno-romantický, lingvo-etnocentrický projekt sa v slovenskej kultúre stabilizoval a kanonizoval najviac cez Hurbanove literárno-historické a literárno-kritické pohlady, ktoré zakonzervovali názor, že slovenský literárny život v uhorských časoch dlhé stáročia iba driemal a rozvíjal sa iba v nepravých a málo (ne)národných formách. Napriek tomu je zaujímavé, že dva klúčové a dodnes platné kanonické texty slovenskej romantickej literatúry, ktoré s Kollárovým Předzpěvom vytvárajú akúsi „kanonickú triádu“, vznikli až po revolúcii 1848 v liberálnejšom tzv. memorandovom období: Smrt' Janošikova (1862), Mor ho! (1864).

Uhorská školská a kultúrna politika po roku 1867 diskriminovala slovenskú národnú elitu, obmedzovala jej možnosti efektívnejšie rozvíjat', kultivovat’ a inštitucionalizovat 
kultúrny a literárny život. V slovenskom etnickom prostredí sa to prejavovalo v rozličných podobách asimilácie či rezignácie časti národnej elity. Slovenská literárna obec bola zväčša slabá a roztrúsená a na prelome storočí sa koncentrovala najmä v evanjelických a čiastočne katolíckych kruhoch a v troch centrách: konzervatívnom Martine a v liberálnej Prahe a Budapešti. Stredné a vyššie slovenské školy neexistovali, takže slovenský literárny život sa ocitol v mŕtvom bode a v porovnaní s českou a mad’arskou literatúrou stagnoval. Čitatelský kánon gramotnej slovenskej populácie vymedzovali skôr konzervatívne profilovaní autori, ako aj slovenské kalendáre či mad’arská a nemecká populárna literatúra. Kontinuitu „vyššieho“ literárneho života zabezpečovalo iba niekol'ko vydavatel'stiev (vrátane cirkevných) a zužujúci sa okruh „slovenských“ spisovatelov a čitatelov. Dôležité je však to, že mnohé literárne diela práve z tohto historického obdobia tzv. slovenského realizmu zostávajú kanonickými textami výrazne reprezentujúcimi sociálne a národnostne nespravodlivý uhorský politický systém, kritický obraz asimilácie, ale aj jadro budúceho mýtu o nezlomnosti a nepoddajnosti malého slovenského človeka počas „tisícročného útlaku“. Literárny kánon sa profiloval v trvalom ideovom aj estetickom spore medzi prísnou obrannou uzavretostou a iluzórnym slovanofilstvom (S. H. Vajanský) a otvoreným (stredo)európskym modernizmom a pragmatizmom (I. Krasko a B. S. Timrava).

Slovenský literárny kánon v intenciách martinského konzervativizmu profiloval redaktor a kritik Jozef Škultéty, autor informatívnych dejín slovenskej literatúry (A tót irodalom története), ktoré pripravil do série dejín svetovej literatúry v mad’arskom jazyku. Ako slovenskú literatúru prezentoval iba literatúru napísanú v slovenskom jazyku, ktorá vznikala až od čias bernolákovskej kodifikácie. Vyčleňovanie a kanonizovanie užšej slovenskej literárnosti obhajoval aj v polemikách najmä s československy orientovanými vzdelancami (A. Pražák, M. Hodža...). ${ }^{15}$ Rok 1918 otvoril slovenskej literatúre nečakané možnosti, ale diskusie o charakter nového autonómneho slovenského literárneho kánonu pokračovali.

\section{prof. PhDr. Peter Káša, CSc.}

Inštitút ukrajinistiky a stredoeurópskych štúdií

Filozofická fakulta, Prešovská univerzita v Prešove

Ul. 17. novembra 1, 08001 Prešov, Slovensko

peter.kasa@unipo.sk

15 V ostatnom čase sa týmto otázkam podrobne venovala ZELENKOVÁ, Anna: Medzi vzájomnostou a nevzájomnostou. Sondy do česko-slovenských a slovensko-českých literárnych vztahov. Praha - Nitra: Slovanský ústav AV ČR, v. v. i. - FF UKF, 2009. 